\title{
DROSERA CAPENSIS: SOME VARIATION IN CULTIVATION AND IN THE WILD
}

RoBerT GIBSON • Cardiff Heights • NSW 2285 • Australia • robert.gibson@environment.nsw.gov.au

\section{Introduction}

The Cape Sundew (Drosera capensis L) is one of best known and most widely grown of all the sundews. It's large size, mobile leaves that fold over prey, and ease of cultivation have made it a popular carnivorous plant to grow and study. Yet it remains poorly known in the wild. To help remedy this, I present a summary of my observations of Drosera capensis in nature, from the study of herbarium specimens and the literature, and cultivated plants to present a current picture of its variation in cultivation and in the wild.

Drosera capensis is a robust perennial sundew that is native to South Africa, and which has been described in detail in recent literature (e.g. Robinson et al. 2017). Plants generally form a semierect rosette to about $25 \mathrm{~cm}$ diameter of narrowly rectangular leaves to about $16 \mathrm{~cm}$ long, that often sit aside a short stem (Fig. 1). Flowers are produced on a scorpioid cyme that has spreading colorless hairs on its peduncle. Each bloom is about $2 \mathrm{~cm}$ across, and usually has pale purple petals. The ovary is surmounted by three sub-horizontal styles that are bifurcated from the base and expand into a terete to an irregularly obovate stigma. Flowers are self-fertile, and autogamous and usually set an abundance of highly viable dark brown

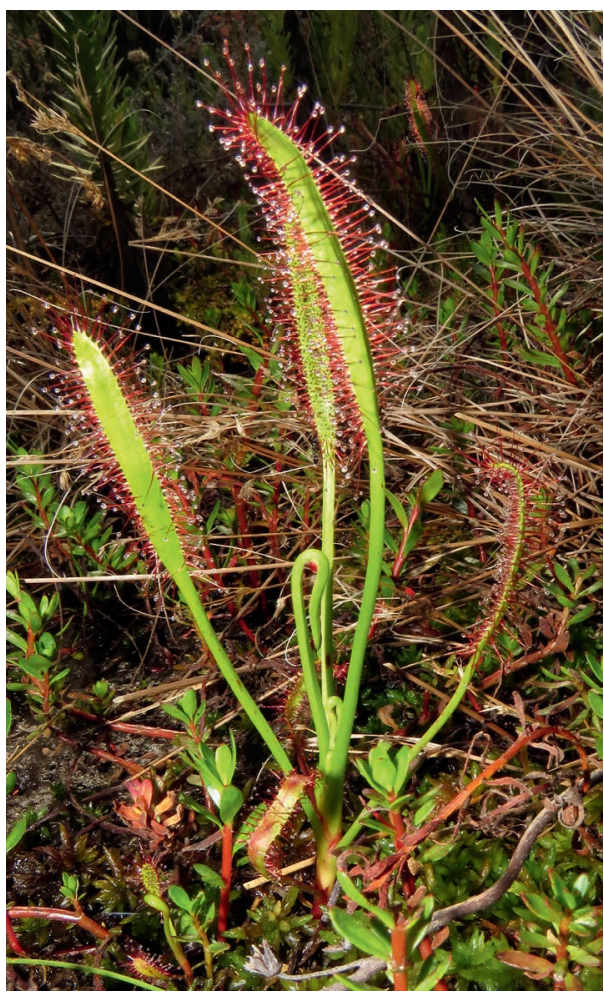

Figure 1: Plant of Drosera capensis at Silvermine Nature Reserve. seeds that are cylindrical in shape and around 0.6$0.8 \mathrm{~mm}$ long by 0.1-0.15 $\mathrm{mm}$ maximum diameter. Seed ripens 4 to 5 weeks after pollination.

\section{Distribution and Ecology}

Despite its strong association with the Western Cape, the Cape Sundew is a widespread species that grows along the entire south coast and adjacent sandstone ranges of South Africa; between Port Elizabeth and Cape Town. It also extends to about $230 \mathrm{~km}$ north of Cape Town along sandstone ranges to Gifberg (Obermeyer 1970) (Fig. 2). This is a species of permanently wet habitats where it is commonly found in permanent seepage zones; in thin moss-covered rock or pockets of alluvium on stream banks or the sides of farm dams; and in peaty soil on the edge of coastal wetlands. It grows from sea-level to about 1800 meters altitude. Plants in the higher elevation sites experience frosty winters and so often have a period of winter-dormancy where they die back to a dormant growing point. 


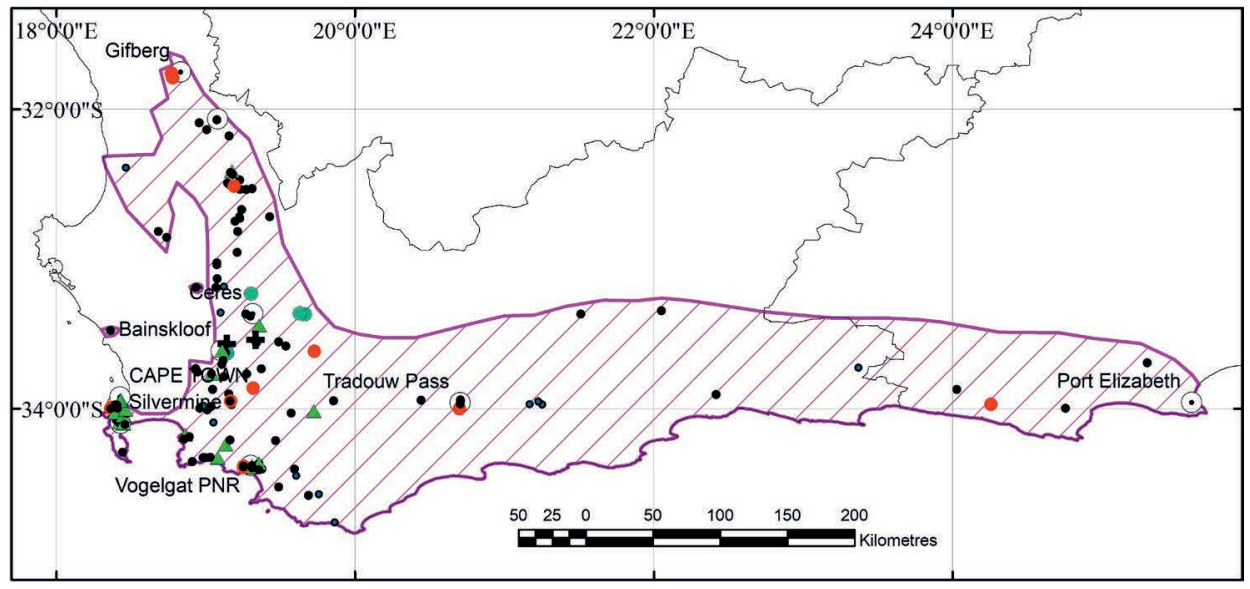

Figure 2: Distribution map of Drosera capensis records. Symbols used wide-leaved form (green triangle), red-leaved plants (red circle), mini-plants (pale blue circle), narrowleaved form (black dots), and Bainskloof form (black cross). Records from the Compton Herbarium, iNaturalist, Obermeyer (1970), and my own observations.

Despite its legendary fecundity, the Cape Sundew is often uncommon and localized in the wild. In September 2017, I saw an exception to this, where D. capensis was the dominant herb over at least a hectare of shrubland in a seep in the Tradouw Pass, about $200 \mathrm{~km}$ east of Cape Town (Fig. 3 ). Sundews grew in abundance after a recent fire had reduced the canopy of the shrubland to an array of slowly-resprouting bare trunks. Drosera capensis was absent from nearby seepages, most of which had also burnt, even though $D$. aliciae grew in all local wetlands. It is not clear what keeps

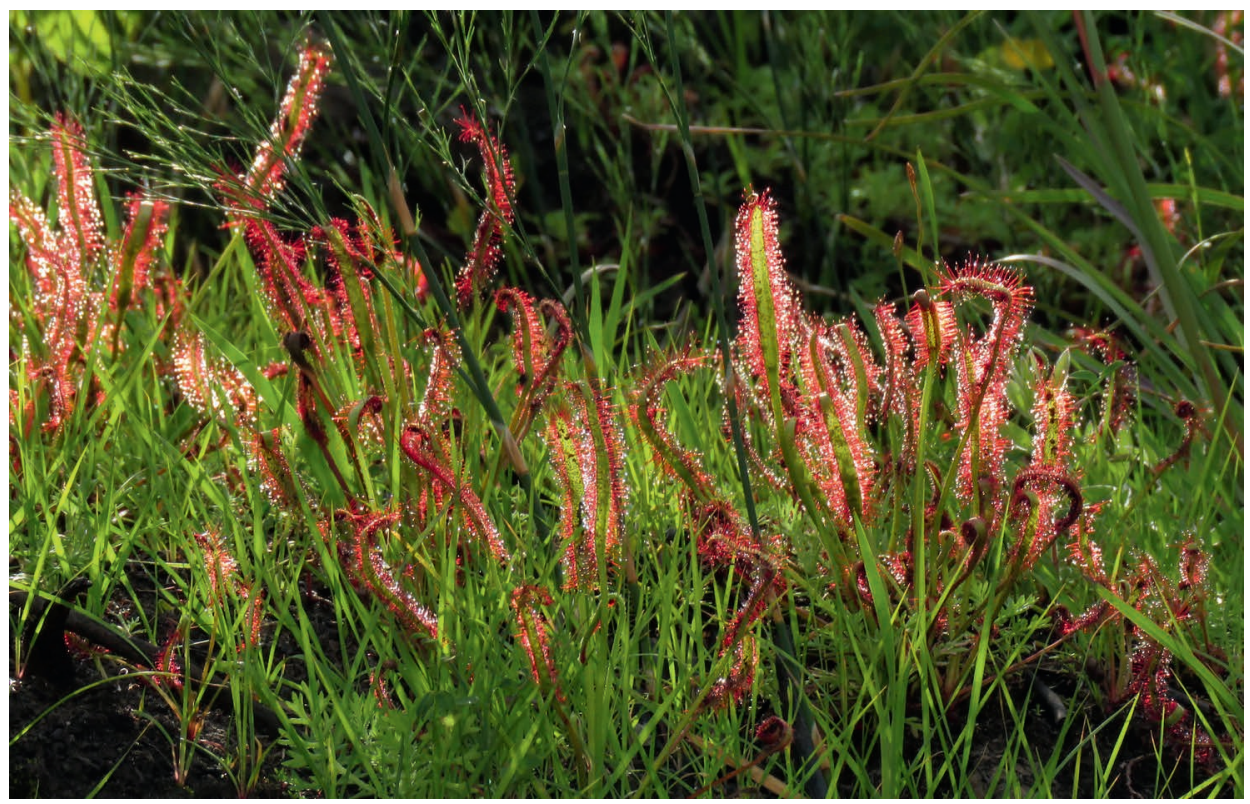

Figure 3: Drosera capensis in the Tradouw Pass. 
D. capensis in check in the wild; its widespread distribution suggests that this species needs more than wind or moving water to spread its seeds over hostile territory. It is curious that this sundew did not spread north of Port Elizabeth, as D. natalensis has done.

\section{The Current Classification}

Adrian Slack (1986: p. 44) described two distinct forms of D. capensis: the 'narrow-leaved' form and the 'typical' form which here will be referred to as the 'wide-leaved' form. These forms differed in relation to the following characters: leaf width; relative widths of the lamina to the petiole; relative lengths of the lamina to the petiole; degree of stem formation; and petal color. To this two-fold informal classification, D'Amato (1998: p. 127-129) added three additional forms, based on plant color and stature: the 'alba', 'red', and 'narrow' forms. It is possible that D'Amato's 'narrow' form may be equivalent to Slack's 'narrow-leaved' form. Further variants have been suggested since then, based primarily on putative location of origin. However, with few exceptions, it is challenging to assign an unlabelled plant to the available informal names due to the short descriptions of each form, and the phenotypic plasticity exhibited by this species (Wang et al. 2015). For this article, leaf dimensions cited are from the longest leaves, produced in early summer. Floral details are required for identification.

\section{'Wide-leaved' form}

The 'wide-leaved' form is the robust version of the species in which the lamina and petiole are both are more than $3 \mathrm{~mm}$ wide and in the petiole is about $60 \%$ the width of the lamina (Fig. 4). The lamina is defined by the presence of insect-trapping hairs, is about the same length as the petiole, and is up to $8 \mathrm{~mm}$ wide. The underside of the leaves has a sparse cover of colorless eglandular hairs. Flowers are large, often around $3 \mathrm{~cm}$ diameter with broadly ovate overlapping petals that are usually dark purple in color. The stigmas are irregularly obovate to elliptic and widen conspicuously from the terete style segments. These plants slowly develop conspicuous stems to $15 \mathrm{~cm}$ tall. This form is also known as the 'broad-leaf' form (GrowSundews.com 2020). Also, many of the 'giant' plants in cultivation are of this form.

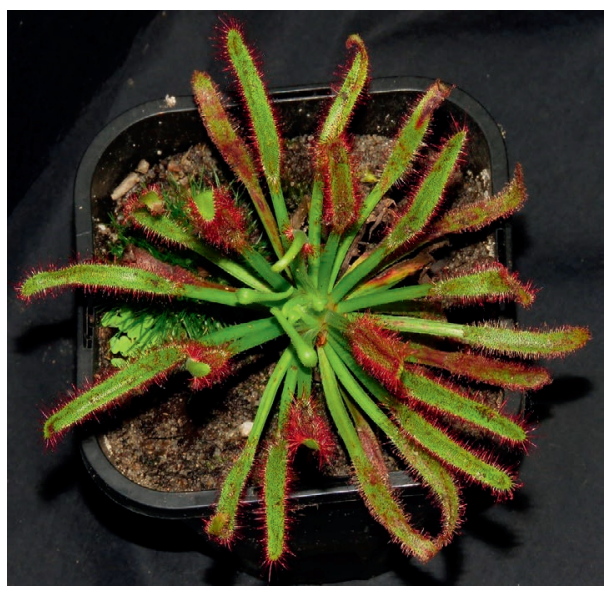

Figure 4: 'Wide-leaved' form of Drosera capensis, with the lamina almost twice as wide as the petiole, and both more than 3 $\mathrm{mm}$ wide.

This form is restricted to the south western part of the Western Cape where is has been recorded at the Silvermine Nature Reserve, Vogelgat Private Nature Reserve, and the former Bergvliet Farm (now part of urban Cape Town). Plants from Vogelgat in cultivation often have pale purple flowers.

\section{'Narrow-leaved' form}

The 'narrow-leaved' form Slack (1986) describes plants with leaves to about $12 \mathrm{~cm}$ long that are of uniform width, or with the lamina up to twice the width of the petiole; and in all cases the leaf is 
no more than about $3 \mathrm{~mm}$ wide. The lamina is about the same length as the petiole and is up to about $3 \mathrm{~mm}$ wide. Leaf eglandular hair cover is similar in density and location to the 'wide-leaved' form. Mature plants may have no obvious stem, but older plants can form stems to $5 \mathrm{~cm}$ long. The overall plant color is olive green, to reddish. The flowers are about $2 \mathrm{~cm}$ diameter and have pale purple petals and terete to narrowly ovate stigmas. This description matches the usual form of the species in the wild, and which has been in cultivation for decades.

\section{Red-leaved plants}

Since at least 1991, red-leaved plants of $D$. capensis have been available in cultivation (ICPS seedbank list, 25 April 1991). These plants are almost identical in size and morphology to the "narrow-leaved' form but the plants turn vibrant red under bright illumination (D'Amato 1998). The leaves in plants cultivated here grow to about $10 \mathrm{~cm}$ long, divided almost equally between lamina and petiole, and with few eglandular hairs on the leaf under surface. Flowers are up to $2 \mathrm{~cm}$ across and have style segments that are dark purple in color and irregularly ovate stigmas.

Most red-leaved plants in cultivation are likely to have come from a roadside seepage site at Gifberg, at the northern end of the species range (Fig. 5). However, red-leaved plants are known from other locations, such as at Travellers Rest, the Koue Bokkeveld plateau, and on Table Mountain (iNaturalist 2020) (Fig. 2). Further study is recommended to see how many of these populations of red-leaved plants have a genetically fixed trait to express red pigmentation or are responding to a transitory stress, such as increased light levels or nutrients following fire.

This form of $D$. capensis was the first sundew to have it full genome determined and published (Butts et al. 2016). During September 2017 , I was able to show the main authors of the paper the plants in the wild.

\section{White-flowered plants}

White-flowered plants of $D$. capensis appears to have emerged spontaneously in cultivation in Western Europe in the 1980s and spread rapidly from there (D'Amato 1998). It is sometimes called D. capensis 'Albino' (GrowSundews.com 2020). Leaf morphology fits with the 'narrowleaved' form of the species. Its flowers are 10 to $14 \mathrm{~mm}$ diameter with white petals and moderately expanded stigmas (Fig. 6). The leaves are a golden green color. The insect trapping hairs have colorless stalks and green to pale red

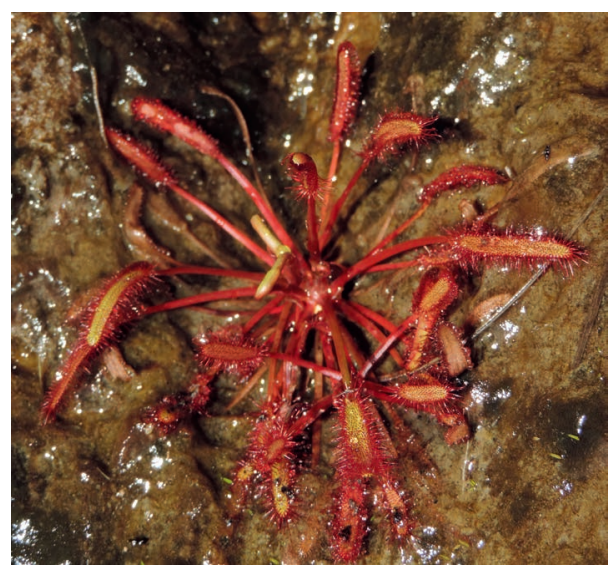

Figure 5: Red-leaved plant at Gifberg.

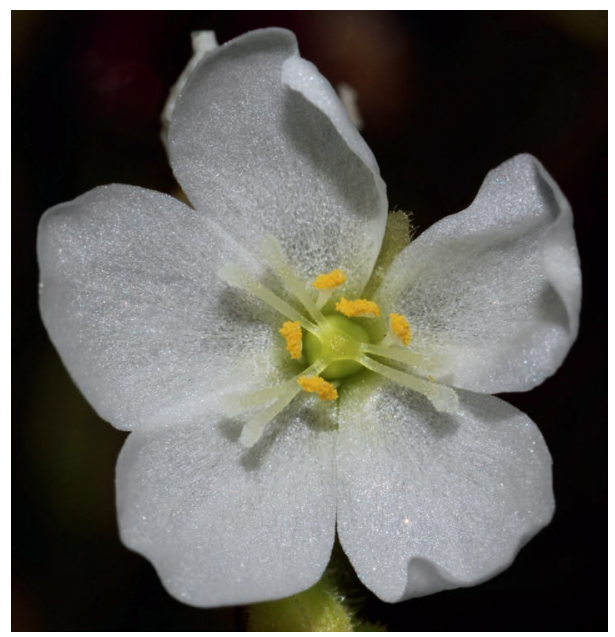

Figure 6: Flower of the 'white petal' form also showing its typically dilated stigmas. 
glands. Such plants have not been reported from the wild. However, I did see white-petalled plants in the Mendocino bog in northern California in August 2018 that may have been deliberately introduced, given the history of the site, rather than having arisen spontaneously from the naturalized population of 'narrow-leaved' form plants there.

Plants with additional insect-trapping hairs

The occasional plant may have additional insect-trapping hairs on one of two organs: the bracteoles and the petals. Occasionally some otherwise typical 'narrow-leaved' form plants develop enlarged bracteoles on the scape that have insect-trapping hairs (Fig. 7A). I have seen such plants in the wild in the Koue Bokkeveld plateau with Eric Green in 1998. This character occurs in some other species of Drosera too, where it may be widespread enough for such plants to be formally recognized, such as D. rotundifolia var. bracteata from Corsica (Baffnay et al. 1985).

The first flowers of a scape of some red-leaved plants develop a row of insect trapping hairs along the mid-vein of the petals (Fig. 7B). It is not known if such glandular hairs have the power of digestion.

\section{Mini-plants}

Plants no more than $10 \mathrm{~cm}$ diameter when mature have been in cultivation for at least 20 years. These plants produce small olive-green semi-erect rosettes to $10 \mathrm{~cm}$ across with a congested stem at most a few $\mathrm{cm}$ long. The petioles are 1.5 to $2 \mathrm{~mm}$ wide and the lamina are 3 to $4 \mathrm{~mm}$ wide. The scape is not proportionately reduced in size compared to the rest of the plants and so towers over the rosettes and has dark purple flowers to about $2 \mathrm{~cm}$ diameter.
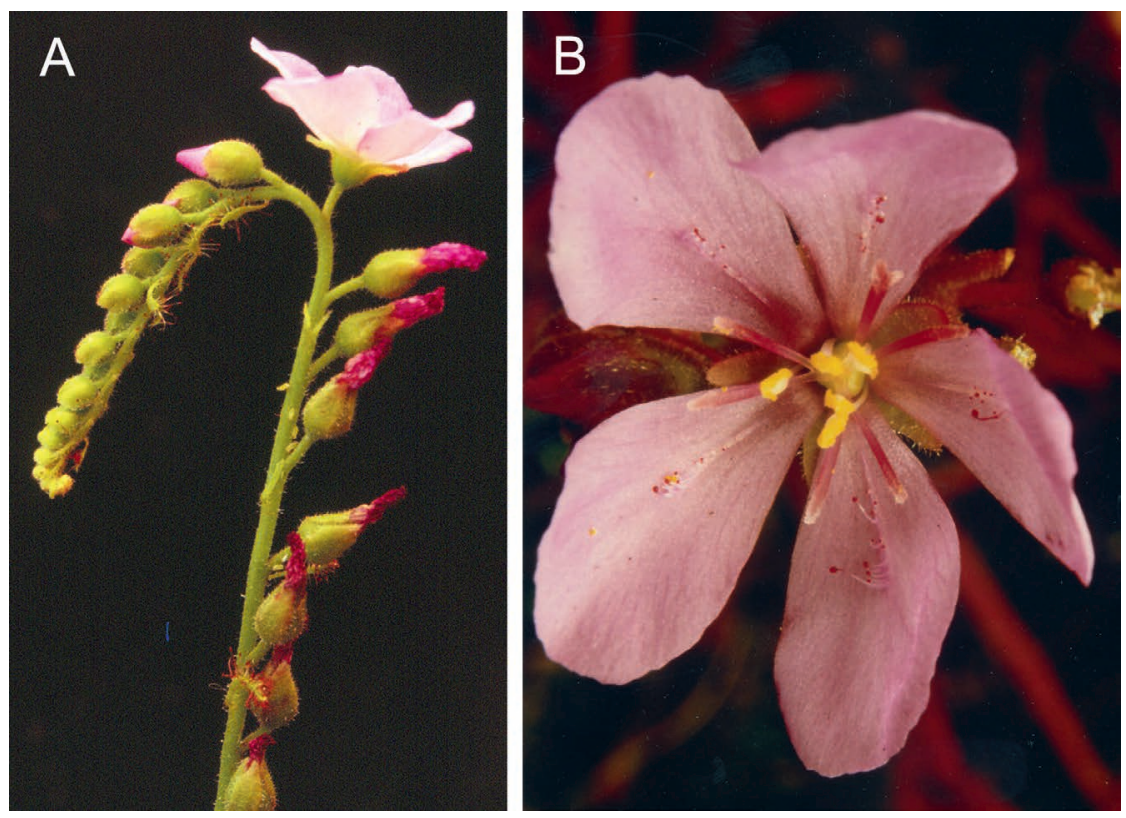

Figure 7: (A) Scape of a plant with enlarged glandular-hairy bracts. (B) Some red-leaved plants produce flowers with a partial row of insect-trapping hairs along their mid-line. 
This poorly known variant has been recorded from the highest peaks around Ceres and Bainskloof, such as Matroosberg, and the upper slopes of Baviaanskloof between about 1000 and 1800 $\mathrm{m}$ altitude respectively. Plants of typical form also occur in this region, and with overlapping altitudinal range, so it is not technically an 'alpine' form but it has many 'alpine' attributes, such as the ability to survive frosty winters with periodic snow falls by dying down to the growing point that is protected by persistent bracts and thermal insulation from the wet habitats in which it grows.

Eric Green had a fascinating tale of the adventure to Matroosberg where he found plants of this form - the likely source of many in cultivation. During this adventure, Eric recounted how each time he thought he was near the top, another slope to climb was revealed. He was with his young grandson who had not seen snow before, and so enjoyed playing in snowbanks; while Eric kept an eye out for chance of encounters with unfriendly wildlife.

\section{Travellers' Rest plants}

In September 2017, I observed very large plants of D. capensis on the banks of the Doring River at Travellers' Rest - east of Clanwilliam (Fig. 8). The plants formed rosettes to about $30 \mathrm{~cm}$ across. The petioles were about $2 \mathrm{~mm}$ wide, and the laminas were about $3 \mathrm{~mm}$ wide. The petioles were longer than the leaf blade. Some plants at the site were fully red in color. Many plants were in flower and had pale purple flowers about $1.5 \mathrm{~cm}$ across, with terete style segments.

A number of plants in cultivation share the trait of the plants at Travellers' Rest by producing leaves with a petiole longer than the leaf blade; up to twice the length. This is the other source of the 'giant' plants in cultivation. Such plants are like a long-leaved variant of the 'narrow-leaved' form.

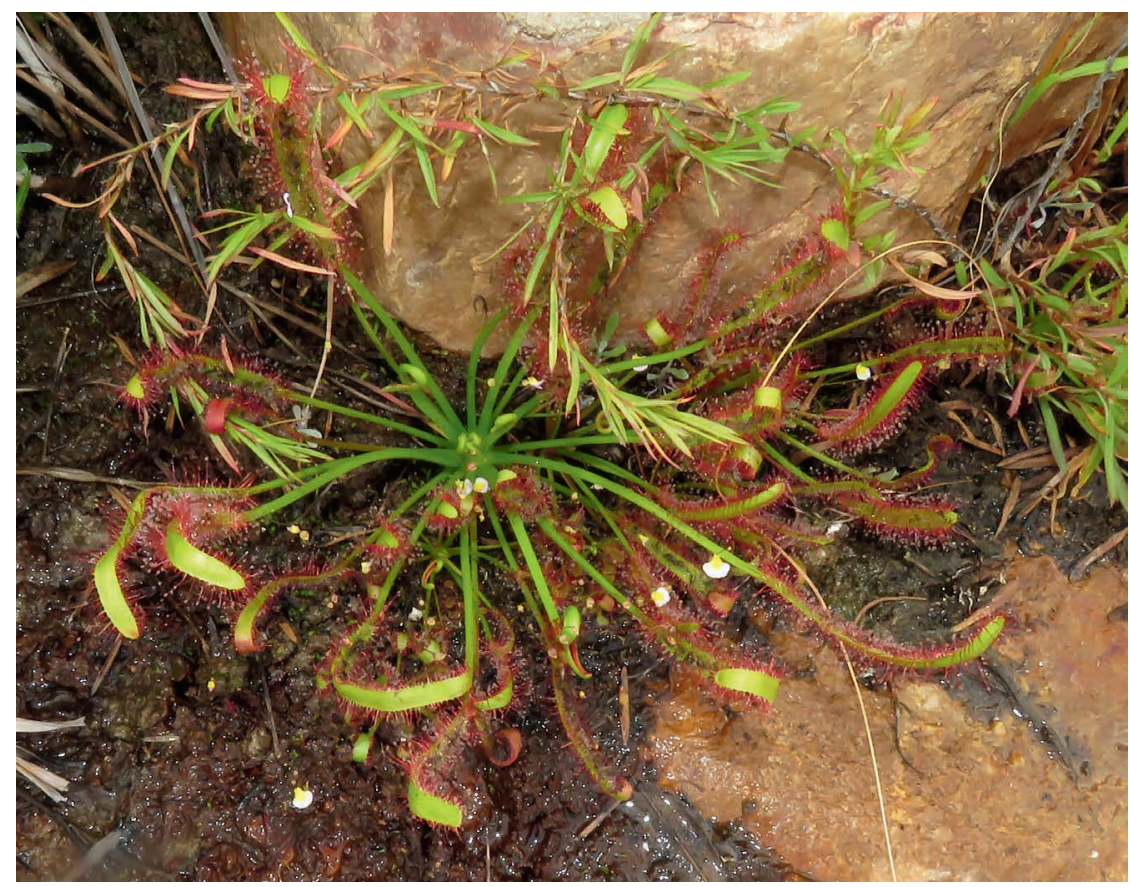

Figure 8: Robust plants of Drosera capensis from Travellers' Rest form rosettes to $30 \mathrm{~cm}$ across. 
Paddle-shape leaved plants

Plants with lamina to around $6 \mathrm{~mm}$ wide on petioles to $2 \mathrm{~mm}$ wide do not fit neatly in the informal two-fold classification. I saw such plants at the top of the Gydo Pass, near Ceres, in September 2017 where plants grew in a sphagnum slurry on the edge of a dam at about 1000 meters altitude. The site experiences frosty winters and the plants were coming out of dormancy. They formed sparse rosettes of semi-erect leaves that reminded me of D. anglica plants (Front Cover). Due to the sodden nature of the site, new plants were seen to spontaneously emerge from older leaves where they were submerged.

A form of paddle-shape leaved plant is known from Bainskloof Pass. These plants also have a distinct internode so that these plants quickly form a conspicuous stem (R. Maharajh, pers. comm., 2020) (Fig. 9). I have yet to see plants of this form. When I looked for such plants in 2017, I saw that D. capensis grows in seepages along about $20 \mathrm{~km}$ of the $\mathrm{R} 301$ road that goes through Bainskloof Pass. However, all of the plants I saw at the time were of the typical 'narrow-leaved' form, which suggests that the stem-forming plants are of limited distribution. Caulescent plants with paddleshaped leaves have been found recently at Waaihoekskloof, near Ceres, about $20 \mathrm{~km}$ east of Bains-

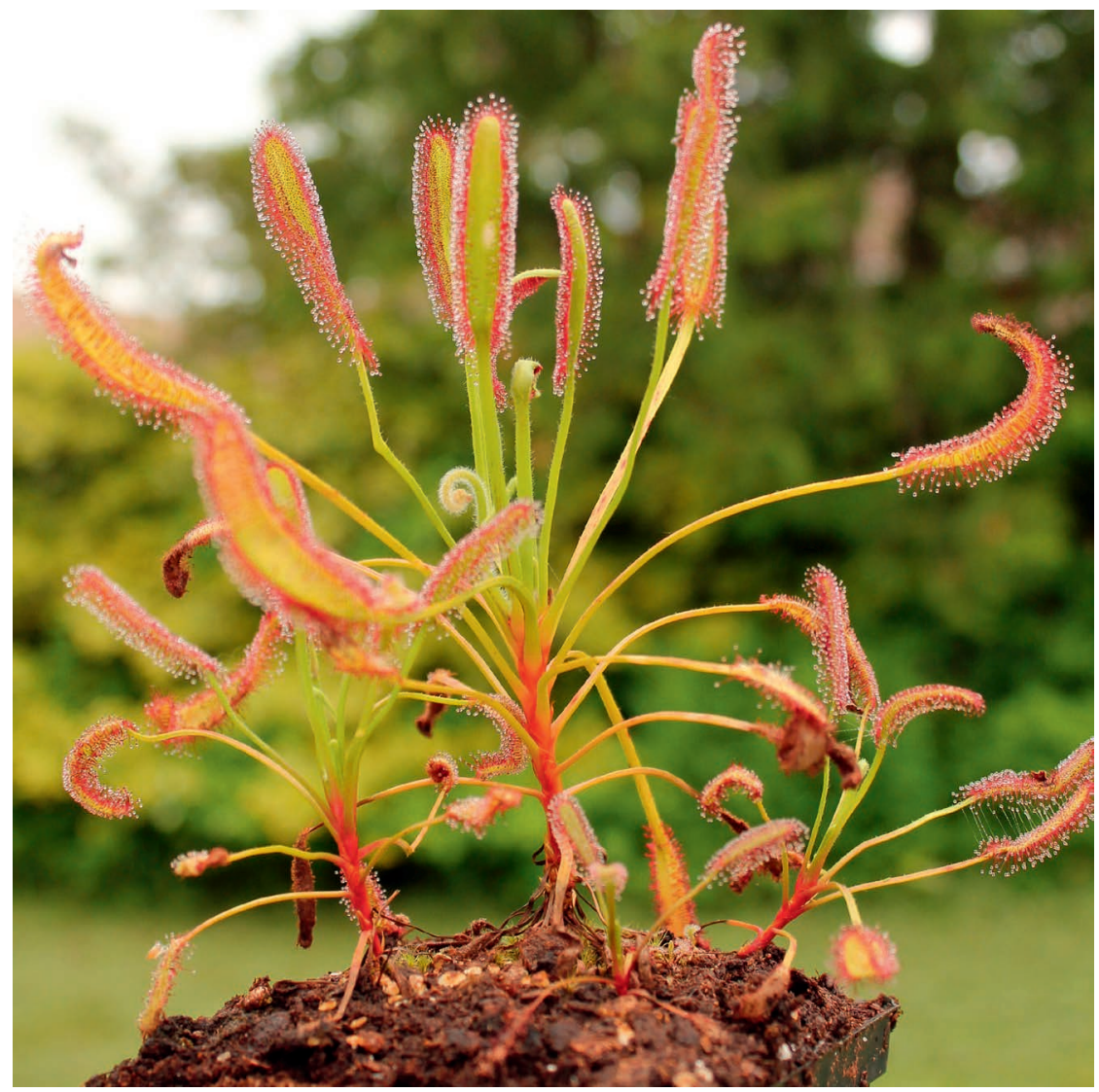

Figure 9: Plants of the "Bainskloof form" of Drosera capensis showing the characteristic paddle-shaped leaves and distinct internodes. Plants grown and photographed by R. Maharajh. 
kloof (iNaturalist 2020). Similar plants have also been reported from Montague Pass, about $400 \mathrm{~km}$ east of Cape Town.

I have grown another 'paddle-leaved' form of $D$. capensis for many years which until recently I had mistaken for the Bainskloof form. However, this form has congested internodes and so forms a stem only very slowly. The leaves are to $6 \mathrm{~cm}$ long, with a petiole to $1 \mathrm{~mm}$ wide and leaf blade to $3 \mathrm{~mm}$ wide, and they are noticeably spirally arranged on the stem. The underside of the leaves is covered with abundant eglandular hairs. The flowers are up to $1.6 \mathrm{~cm}$ across and have dark purple petals. The stigmas are dark purple and are irregularly obovate in shape. This form of the species came from Richard Sullivan, but it is not clear where it came from in the wild.

\section{Summary and Conclusions}

Drosera capensis is a well-known and widely studied species due to its large size, dramatically mobile leaves, and ease of cultivation. However, the link between cultivated plants and plants in the wild has been rarely described, so that it has not been made clear before that the 'typical' ('wideleaved' form) plant in cultivation (sensu Slack 1986) is not the typical form of the plant in the wild.

I present a summary of some of the natural variation in the species and hope I have presented a framework to better understand this beautiful sundew; one that has many more secrets to reveal.

Acknowledgements: I thank John Brittnacher, Greg Bourke, Christian Dietz, Gunter Eitz, Andreas Fleischmann, Eric Green, Kirk 'Füzzy' Hirsch, Robert and Michelle Kunitz, Rob Maharajh, Stewart McPherson, Fernando Rivadavia, Gordon Snelling, and Richard Sullivan for discussions on this species. Many of them also accompanied me see this species in the wild. I also thank the director and staff of the Compton Herbarium, Cape Town, for study access to their collections.

\section{References}

Baffnay, M., Brice, F., and Danton, P. 1985. Les Plantes Carnivores de France: Histoire, Botanique, Uses. Seuences, Aigre, France.

Butts, C.T., Bierma, J.C., and Martin, R.W. 2016. Novel proteases from the genome of the carnivorous plant Drosera capensis: Structural prediction and comparative analysis. Protein 84 (10): 1517-1533.

D’Amato, P. 1996. The Savage Garden: Cultivating Carnivorous Plants. Ten Speed Press, Berkeley. GrowSundews.com. 2020. Drosera capensis - The Cape Sundew varieties. http://www.growsundews. com/sundews/Drosera_capensis.html. Accessed 3 September 2020.

iNaturalist. 2020. Drosera capensis. https://www.inaturalist.org/observations?taxon_id=52656. Accessed 28 August 2020.

Obermeyer, A.A. 1970. Droseraceae. In: L.E. Codd, B. de Winter, D.J.B. Killick, and H.B. Rycroft (Eds.). Flora of Southern Africa 13. Pretoria. pp. 187-201.

Robinson, A., Gibson, R., Gonella, P., McPherson, S., Nunn, R., and Fleischmann, A. 2017. Drosera of the World: Volume 3. Redfern Natural History Productions, Poole.

Slack, A. 1986. Insect-eating Plants and How to Grow Them. Alpha Books, Poole.

Wang, D.-H., Wang, D.-Q., Cui, Y.-W., Yang, L., Gu, X.-D., Song, W.-F., and Li, F. 2015. Photoperiod regulates Cape Sundew (Drosera capensis) gland secretion and leaf development. Carnivorous Plant Newsletter 44: 197-203. 


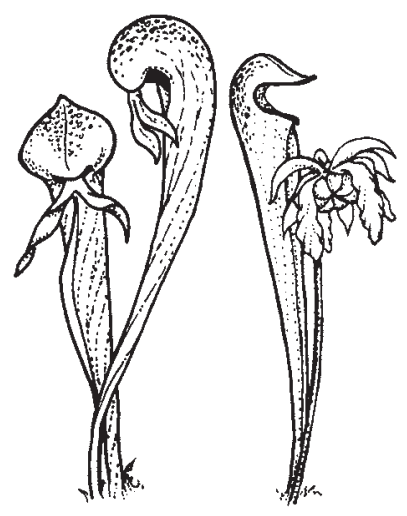

\section{CARNIVOROUS \\ PLANT \\ NEWSLETTER}

Journal of the International

Carnivorous Plant Society

www.carnivorousplants.org

\section{Volume 49, Number 4 December 2020}

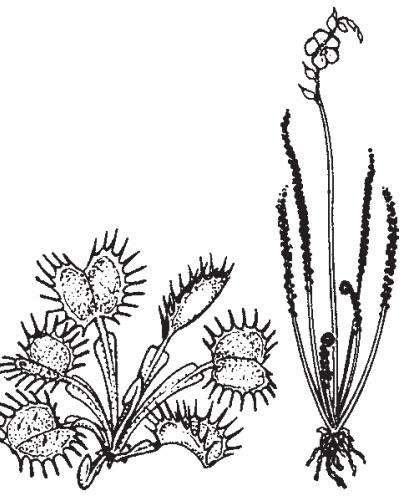

Front Cover: Plants of a 'paddle-leaf' form of Drosera capensis regrowing after winter dormancy at the top of the Gydo Pass. Photo by Robert Gibson. Article on page 173.

Back Cover: Nepenthes mapuluensis illustration by François Sockhom Mey. Article on page 148.

Carnivorous Plant Newsletter is dedicated to spreading knowledge and news related to carnivorous plants. Reader contributions are essential for this mission to be successful. Do not hesitate to contact the editors with information about your plants, conservation projects, field trips, or noteworthy events. Advertisers should contact the editors. Views expressed in this publication are those of the authors, not the editorial staff.

All correspondence regarding dues, address changes and missing issues should be sent to the Membership Coordinator at the ICPS. Do not send such correspondence to the editors. Checks for subscriptions should be made to the International Carnivorous Plant Society in US funds. Dues, including a subscription, are \$30 per year.

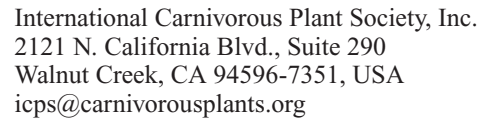

President

Vice President

Secretary

Treasurer

Board Member

Board Member

Board Member

Board Member

Board Member

Membership Coordinator

Webmaster

Media Coordinator

Seed Bank Manager

CPN Editors

Managing Editor

Editor

Editor

Editor

Science Editor

Science Editor

Science Editor

\begin{abstract}
Richard Nunn, richardnunn@carnivorousplants.org
John Brittnacher, john@carnivorousplants.org

Cindy Slezak, cindy@carnivorousplants.org

Daniela Ribbecke, daniela@carnivorousplants.org

Brent Jones, brent@carnivorousplants.org Bob Ziemer, bob@carnivorousplants.org

Cindy Slezak, cindy@carnivorousplants.org

John Brittnacher, john@carnivorousplants.org

Chad Williams, chad@carnivorousplants.org

Joe Griffin, joe@carnivorousplants.org

editor@carnivorousplants.org

Bob Ziemer

Barry Rice

Karl Herold

John Brittnacher

Andreas Fleischmann

Fernando Rivadavia

Jan Schlauer
\end{abstract}

Kenny Coogan, Education Director, kenny@carnivorousplants.org

Jan Schlauer, Cultivar Registrar, jan@carnivorousplants.org

Carson Trexler, Conservation Director, carson@carnivorousplants.org

Date of effective publication of the September 2020 issue of Carnivorous Plant Newsletter: August 6, 2020.

The ICPS is the International Cultivar Registration Authority (ICRA) for the names of cultivated carnivorous plants according to the International Code of Nomenclature for Cultivated Plants. Send relevant correspondence to the ICPS, Inc.

Carnivorous Plant Newsletter is published quarterly in March, June, September, and December by the ICPS, Inc., 2121 N. California Blvd., Suite 290, Walnut Creek, CA 94596, USA. Periodicals postage paid at Walnut Creek, CA and additional mailing offices. Postmaster: Send address changes to ICPS, Inc., 2121 N. California Blvd., Suite 290, Walnut Creek, CA 94596, USA. Printed by Allen Press, Inc., 810 E. 10th Street, Lawrence, KS 66044. Logo and masthead art: Paul Milauskas. (C) 2020 International Carnivorous Plant Society. All rights reserved. ISSN \#0190-9215 